\title{
YKSIN TULLEET NUORET HALLINNAN
KOHTEENA: SUOMALAINEN YHTEISKUNTA
NÄKÖALATTOMUUDEN VAI TOIVON
RAKENTAJANA?
}

Anna-Kaisa Kuusisto: HT, polittisen maantieteen dosentti, Tampereen yliopisto

Kristiina Korjonen-Kuusipuro: FT, kulttuuriantropologi, Tampereen yliopisto

anna-kaisa.kuusisto@uta.fi; kristiina.korjonen-kuusipuro@uta.fi

Janus vol. 26 (4) 2018, 370-378

JOHDANTO

Yksin matkaavia nuoria ja lapsia on aina liikkunut pakolais- ja väestövirtojen mukana, mutta viime vuosina heitä on ollut globaalisti enemmän kuin koskaan aikaisemmin. Vuoden 2015 aikana ilman huoltajaa saapuneita alaikäisiä tuli EU:n alueelle lähes 95000 ja vuoden 2016 aikana 63 000. Tämä märä jakautui eri Euroopan valtioihin hyvin epätasaisesti. Esimerkiksi vuonna 2015 Ruotsista turvapaikkaa päätyi hakemaan hieman yli 35 000, Saksasta 22250 ja Suomesta hieman yli 3 000 yksin tullutta lasta ja nuorta. EU:n tiukka rajakontrolli ja rajatarkastukset myös Schengen-alueen sisällä ovat vähentäneet kaikkien turvapaikanhakijoiden määrää. Yksin tulleita saapuikin Suomeen vuonna 2017 enää 142. Ilman huoltajaa turvapaikkaa hakevien alaikäisten määrän suuri vaihtelu on aiheuttanut ongelmia vastaanottovaiheen majoituksessa, turvapaikkahakemuksien käsittelyssä ja kuntapaikkojen järjestämisessä oleskeluluvan myöntämisen jälkeen. Nuorten arkea kuormittavat muun muassa vastaanottovaiheen asumisyksiköiden sulkemisista johtuvat nuorten siirtymiset Suomen sisällä, pitkittyneet hallinnolliset prosessit sekä yleinen epävarmuus omasta tulevaisuudesta ja mahdollisesti kotimaahan jääneen perheen tilanteesta. Vaikka Suomessa ilman huoltajaa saapuvien lasten ja nuorten hoivantarpeeseen on pääsääntöisesti pystytty vastaamaan riittävästi, on hoivakäytännöissä ja niitä ohjaavissa laeissa paljon kehitettävää, jotta yksin tulleiden hyvinvoinnin pitkäjänteinen turvaaminen olisi mahdollista (Kuusisto-Arponen 2016a, 36-38).

Yksin maahan tullut nuori tarvitsee paitsi turvallisen fyysisen myös sosiaalisesti hyväksyvän ympäristön, jonka avulla kotoutuminen uuteen maahan voi alkaa. Hän tarvitsee luotettavia aikuisia ja ennen kaikkea ystäviä uudesta kotimaastaan. Kuuluminen voidaan nähdä vuorovaikutusprosessina, jonka rakentumiseen vaikuttavat ihmisiä ympäröivien paikkojen historialliset, rakenteelliset ja kulttuuriset tekijät (Reed-Danahay \& Brettel 2008). Suomen Akatemian rahoittamassa yksin tulleiden sosiaalisen tuen kehittämiseen pyrkivässä TRUST-kärkihankkeessa korostammekin kuulumisen tunteen merkitystä, jonka rakentumista nuorten arjessa tulisi kaikin tavoin tukea ja vahvistaa. Nykyinen maahanmuuttopolitiikka sekä hoivakäytännöt suhtautuvat näihin nuoriin usein hallinnan kohteina eivätkä näin ollen tunnista nuoria aktiivisina oman elämänsä asiantuntijoina. Arjessa toimimattomat käytännöt luovat nuorten elämään näköalattomuutta, epävarmuutta ja jopa pelkoa. TRUST-hankkeessa on lähdetty kehittämään uusia ratkaisuja hoiva- 
käytäntöihin ja näin tukemaan nuorten omaa ääntä sekä tarveperustaisten palveluiden luomista.

Tässä puheenvuorossa tarkastelemme yksin maahan tulleiden nuorten huolenaiheita ja ylipäätään heidän kokemuksiaan hallinnan kohteena elämisestä. Keskustelemme erityisesti viime vuosien maahanmuuttopolitiikan muutoksista johtuvista kehityskuluista, kuten perheenyhdistämisen loppumisesta sekä kielteisten oleskelulupien ja jatkuvan odottamisen luomasta näköalattomuudesta. Tämän jälkeen tarkastelemme toivon luomista ja ylläpitämistä keskeisenä yhteiskuntaa kasassa pitävänä käytäntönä. Näkemyksemme mukaan yksin tulleiden, kuten kaikkien maahanmuuttajien, kotoutumiseen tarvitaan toimivat hoivan, asumisen ja sosiaalisen tuen palvelurakenteet. Tämä ei kuitenkaan yksin riitä, vaan yhteiskuntien kyky luoda myötätuntoa ja ylläpitää toivoa on välttämätön kotoutumisen osa.

\section{Mitä NÄKÖALATTOMUUS TARKOITTAA NUORTEN ARJESSA?}

Tällä hetkellä ilman huoltajaa maahan tulleet nuoret ovat voimakkaiden maahanmuuttopoliittisten toimien kohteena. Näitä ei suinkaan aina määritä inhimillinen kohtelu vaan kansallisesti värittyneet poliittiset päämäärät, $\mathrm{ku}-$ ten kansallisvaltion rajojen suojelu ja maahanmuuton rajoittaminen. Yksin tulleilla on usein takanaan traumaattisia kokemuksia entisistä kotimaistaan ja yhä useammin myös matkalta läpi Euroopan. Näistä selviämiseen nuoret tarvitsevat varsinkin vastaanottovaiheen alussa psykologista tukea. Usein nämä nuoret elävät kulttuurien ristipaineessa, jossa lapsuudessa omaksutut kulttuuriset käytännöt törmäävät ja sekoittuvat uusiin. Useampaan kulttuuriin kuuluminen vetää nuoren mieltä eri suuntiin ja tuottaa epävarmuutta. Tässä tilanteessa tarvitaan koti, jossa voi kasvaa aikuiseksi rauhassa. Koti, jossa uudesta kulttuurista voi keskustella, sitä voi ihmetellä ja myös kritisoida ilman pelkoa. Koti, jossa aikuiset ohjaavat, tukevat sekä kannustavat uuden elämän alkuun. Vaikka Suomessa on pystytty huolehtimaan yksin tulleiden perustarpeista asumisen suhteen, eivät nykyiset ratkaisut aina pysty riittävän hyvin tunnistamaan nuorten sosiaalisia ja kulttuurisia tarpeita. Näkemyksemme mukaan yksin tulleiden asumisen ratkaisut ovatkin liian tiiviisti kytköksissä maahanmuuttopolitiikan suunnanmuutoksiin ja ne jatkavat näköalattomuuden kokemusten kerryttämistä nuorten elämässä.

Vuoden 2015 aikana alaikäisyksiköiden määrä lähes kymmenkertaistui Suomessa. Nämä olivat ensisijassa vastaanottovaiheen asumisyksiköitä eli ryhmäkoteja ja usein kansanopistojen tiloissa sijainneita tukiasuntoloita. Tukiasuntoihin sijoitettiin yli 16-vuotiaita, mutta ongelmaksi näiden osalta osoittautui liian vähäinen henkilökuntamitoitus. Tukiasunnoissa voi asua enintään 40 nuorta ja 10:tä nuorta kohden tulee olla kolme aikuista. Tämä henkilökuntamitoitus on täysin riittämätön ottaen huomioon nuorten erityisen sosiaalisen ja psykologisen tuen tarpeen. Ryhmäkotien henkilökuntamitoitus sen sijaan perustuu Lastensuojelulakiin ja niissä asuu maksimissaan 24 lasta. Näissä yksiköissä seitsemää lasta kohden tulee pääsääntöisesti olla seitsemän hoito- 
ja kasvatustehtävissä olevaa henkilöä. Tarvittavan hoivan ja sosiaalisen tuen näkökulmasta eri tyyppisissä asumisyksiköissä elävät nuoret ovatkin eriarvoisessa asemassa. (Kuusisto-Arponen 2016a; Kuusisto-Arponen ym. 2017.)

Sosiaalisen tuen ja asumisen ratkaisut ovat Suomessa ylipäätään jääneet jälkeen siitä yhteiskunnallisesta tilanteesta, missä yksin tulleet tällä hetkellä elävät. Ennen vuotta 2010 ryhmä- ja perheryhmäkoteja pidettiin väliaikaisina asumisratkaisuina ja ainakin osa yksin tulleista sai perheensä Suomeen. Nyt perheenyhdistäminen on näiden lasten ja nuorten kohdalla lähes kokonaan loppunut. Tästä syystä he joutuvat elämään institutionaalisen hoivan varassa koko nuoruutensa. Alaikäinen perheenkokoaja on aikuisia huonommassa asemassa, koska yhdistämisprosessin käynnistäminen vaatii huomattavia taloudellisia ja henkisiä resursseja. Usein kotimaahan jääneellä perheellä ei ole tarvittavia henkilöllisyys- tai matkustusdokumentteja, jonka lisäksi perheen taloudellinen tilanne on usein heikko. (Kuusisto-Arponen 2016b: 97-99.)

Vuonna 2016 käyttöön otettu tuloraja koskee pääsääntöisesti myös alaikäistä perheenyhdistäjää. Nämä perheenyhdistämisen perusteisiin liittyvät kiristykset ovat osuneet poikkeuksellisen kovina ilman huoltajaa tulleisiin. Perheettömäksi suojelu on luonut täysin uudenlaisia ongelmia kotoutumiseen ja kuulumisen tunteen rakentamiseen. On ymmärrettävää, että nuorten on nykyisessä tilanteessa vaikea luottaa heidän kanssaan työskenteleviin aikuisiin sekä sitoutua kotoutumiseen, koska heidän tulevaisuutensa Suomessa on jatkuvasti uhattuna. Erilaiset huhupuheet oles- kelulupien perusteista, mahdollisista maasta poistamisista ja toisaalta tarvittavista kotoutumistoimista luovat ahdistusta nuorten elämään. He kokevat, että ovat jatkuvan odottamisen tilassa, jossa heidän ei kuitenkaan ole mahdollista vaikuttaa oman elämänsä valintoihin tai suuntaan.

Ennen vuotta 2015 yksin maahan tulleet saivat äärimmäisen harvoin kielteisiä turvapaikkapäätöksiä. Nyt oleskelupien kriteereitä on tiukennettu ja niin kutsuttu humanitaarinen suojelu poistui oleskeluluvan perusteista (Migri, tiedote 17.5.2016). Tämän oleskeluluvan perusteen poistaminen on vaikuttanut erityisesti yksin tulleisiin nuoriin. Myönnetyt oleskeluluvat ovat usein myös lyhyitä. Nuoret, jotka ovat jatkolupaa hakiessaan täyttäneet 18 vuotta, saavat yhä useammin kielteisen päätöksen. Nämä käytännöt toteuttavat yhä tiukentuvaa maahanmuuttopolitiikkaa. Nuorten arjessa työskentelevät ihmiset puhuvatkin "järkyttävästä käänteestä" ja pohtivat kykyään toimia ammattieettisesti osana järjestelmää,jossa pyrkimyksenä ei enää tunnu olevan laadukas kotoutumisprosessi, vaan mahdollisimman suuren ihmismäärän nopea ja tehokas käsittely.

Seuraava katkelma kenttätyömuistiinpanoistamme osoittaa, kuinka esimerkiksi oleskelulupapäätösten jatkuva odottaminen lisää epävarmuuden tunnetta arjessa. Myös se, että nuori haluaa kertoa tästä tutkijalle, jonka hän on tavannut vain muutaman kerran aikaisemmin, osoittaa kuinka merkittävästä asiasta on kyse. 
Malik* jatkaa maalaamista. Hän tulee aivan minuun kiinni, painaa pään alas, ei katso minua, mutta alkaa pian puhumaan:

-"Ei tiedä mitä minun käy. Ei tiedä, kun lappu tulee."

- Tarkoitatko oleskelulupaa?.

-Joo, ei tiedä mihin mä joutuu. Ehkä Espooseen.

-Onko sinulla siellä jotain tuttuja?

-Ei mulla ole ketään tuttuja Suomessa.

-No toivotaan, että sä pääset paikkaan, jossa sä tunnet näitä muita nuoria.

( $\star$ nimi muutettu)

Kenttätöissämme huomasimme, kuinka nuoret ovat ylipäätään alkaneet reagoida käytöksellään tiukkenevaan politiikkaan ja sen soveltamiseen. Erilaiset häiriöt ovat lisääntyneet ja asumisyksiköissä on jouduttu uudenlaiseen tilanteeseen. Sääntöjä ja valvontaa on tiukennettu ja perheenomainen yhteisöllisyys on vähentynyt. "Ei olla enää yhtä suurta perhettä, mutta meillä on perhehetkiä", erään asumisyksikön työntekijä totesi meille vierailumme aikana. Tässä tilanteessa lähelläkin olevat aikuiset näyttävät nuorten näkökulmasta olevan osa sitä järjestelmää, joka on osittain eri puolella kuin he itse. Ei ole ihme, että nuoret nykytilanteessa miettivät, onko omalla kotoutumisella mitään merkitystä, jos kielteinen päätös kaikesta huolimatta uhkaa ja he voivat joutua palautetuksi entiseen kotimaahansa vastoin omaa tahtoaan.

Kiristynyt maahanmuuttopolitiikka on synnyttänyt tilanteen, jossa yksin maahan tulleita halutaan poistaa maasta ennätysmäärä. Pitkittyneiden päätöksentekoprosessien aikana monet nuoret ovat alkaneet jo kotoutua Suomeen. Aamulehti kirjoitti huhtikuussa 2018, kuinka nuorten kotoutuminen vaikeutuu, koska lyhyet oleskeluluvat ja niiden jatkot luovat jatkuvan odottamisen kierteen. Usealle 18 vuotta täyttäneelle oleskeluluvan jatkosta on tullut kohtalon kysymys. Suomalainen kotoutumispolitiikka näyttäytyykin sangen omituisena: nuoret ovat sitoutuneet kotoutumiseen heiltä vaaditulla tavalla ja hoitaneet velvoitteensa. Tästä huolimatta yhteiskunta on ajamasta heitä ulos maasta. Nuorten kanssa pitkään työskennelleiden henkilöiden mukaan "sopeutumisesta" on tehty taito, johon päätöksien retoriikassa vedotaan, kun nuori poistetaan maasta. Koska nuori näyttäisi sopeutuvan nopeasti uuteen yhteiskuntaan, hänen oletetaan sopeutuvan palautukseenkin. Tämä on erityisen julma oletus ja vastoin kotoutumisen sekä inhimillisen maahanmuuttopolitiikan ideaalia. Alati tempoilevien käytäntöjen ja näköalattomuuden sijaan Suomen kuuluisi luoda vastuullista ja lapsen edun huomioivaa turvapaikkapolitiikkaa. Käytännössä tämä edellyttää lyhyistä ja määräaikaisista oleskeluluvista luopumista sekä perheenyhdistämisen kriteereiden tarkistamista. Seuraavaksi esittelemme kahden kansainvälisen esimerkin kautta, miten yhteiskunnallisen toivon luominen on toimivan ja osallisuutta korostavan kotoutumisen sekä kuulumisen tunteen ytimessä.

\section{TOIVON LUOMINEN} KOTOUTUMISEN YTIMESSÄ

Antropologi Ghassan Hage (2003) on kirjoittanut, että yhteiskunnan tehtävänä on jakaa toivoa. Yhteiskunta tuottaa jäsenilleen monenlaista tunteisiin liittyvää kiintymystä (esimerkiksi huolehtiminen tai välittäminen), mikä 
on kiinteästi yhteydessä yhteiskunnan kykyyn luoda ja jakaa toivoa. Hage on tarkastellut toivoa erityisesti kansallisvaltioiden ja nationalismin yhteydessä ja painottanut kansallisuuden ja siihen liittyvien oikeuksien merkitystä. Hän on korostanut myös sisä- ja ulkopuolisuuden merkitystä toivon luomisessa. Tällä hän tarkoittaa sitä, että yhteiskunta sulkee esimerkiksi maahanmuuttajat hyvin konkreettisesti ulkopuolelleen eristämällä heidät pakolaisleireille odottamaan. (Ks. myös Hage \& Papadopoulos 2004, 112-114.) Tämä on tärkeä huomio yksin tulleiden kuulumista tarkasteltaessa, sillä myös hoivaava yhteiskunta voi sulkea nämä nuoret muun yhteiskunnan ulkopuolelle erilaisiin tukea tarjoaviin laitoksiin.

Toivo suuntautuu aina tulevaisuuteen ja sisältää niin mahdollisuuksia kuin epävarmuuttakin. Tutkimuksissa toivoa on usein pidetty epämääräisenä, ainoastaan yksilön käyttäytymiseen liittyvänä piirteenä. Se on paikoin yhdistetty perusteettomaan, reaalimaailmasta irrallaan olevaan optimismiin ja saavuttamattomien utopioiden tavoittelemiseen. Nykytutkijat näkevät toivon merkityksellisenä sekä yksilön että yhteisön kannalta. Näiden sosiaalisten merkitysten lisäksi toivolla on laajempikin yhteiskunnallinen merkitys: toivo mahdollistaa toimimisen paremman elämän ja paremman tulevaisuuden puolesta. Toivoa omaavat yksilöt pystyvät toimimaan myös poliittisilla areenoilla, mikä saattaa merkitä mahdollisuuksia parempaan tulevaisuuteen kaikille tietyn ryhmän jäsenille. (Hage 2003; Kleist 2015; Mattingly \& Jensen 2015; Pedersen \& Liisberg 2015.)
Kotoutumisen tukirakenteet ovat eri valtioissa erilaisia. Niiden olemassaolon toteamisen lisäksi on tärkeätä tarkastella myös keitä nämä rakenteet tukevat, missä vaiheessa kotouttamistoimia tehdään ja millainen hallinnan pyrkimys rakenteiden taustalla vaikuttaa. Kuinka ja keiden hyväksi nämä rakenteet käyttävät valtaansa?

Vierailimme helmikuun 2018 alussa Melbournessa, Australiassa sijaitsevassa Noble Parkin peruskoulussa, jossa halutaan taitojen opettamisen lisäksi luoda toivoa lasten elämään. Koulu sijaitsee alueella, jossa asuu paljon maahanmuuttajataustaista väestöä eri kulttuureista. Alueella asuu noin 30000 henkeä, joista 76,5 prosentilla molemmat vanhemmat ovat syntyneet Australian ulkopuolella (Australian keskiarvo on $34.4 \%)$. Asukkaiden työttömyys on yleisempää ja tulo- ja koulutustaso ovat matalammat kuin Australiassa tai Victorian osavaltiossa keskimäärin. Alueella asutaan myös yleisemmin vuokralla kuin muualla Australiassa. (Australian Bureau of Statistics 2016; Australian Social Trends 2014). Noble Park on valtion ylläpitämä koulu, jossa oppilaille on päätetty tarjota mahdollisimman hyvät eväät tulevaisuuteen riippumatta siitä, mistä ja millaisista oloista he tulevat. Tätä tavoitetta on tietoisesti lähdetty toteuttamaan pedagogisin keinoin. Koulussa toteutettavia arvoja ovat kunnioitus (respect), vastuullisuus (responsibility), yhtenäisyys (integrity) ja optimismi (optimism), joita toteutetaan kaikissa ihmisten välisissä suhteissa (relationships). Noble Parkissa oppimisen lähtökohta on suhteiden luomisessa.

Suhteilla on neljä ulottuvuutta: oppilaiden keskinäiset suhteet, oppilaiden 
ja koulun henkilökunnan väliset suhteet, henkilökunnan keskinäiset suhteet ja oppilaiden suhde ympäristöön sekä laajempaan yhteiskuntaan. Oppimista katsotaan tapahtuvan kaiken aikaa ja opetuksessa hyödynnetään koulun laajaa piha-aluetta, jota on rakennettu luontoa kunnioittaen ja luonnonmateriaaleja hyödyntäen. Oppilailla on koulun pihalla oma kasvimaa ja pieni kanatarha, joiden hoito on osa koulunkäyntiä. Noble Parkin tilojen suunnittelussa on hyödynnetty leikkipedagogiikkaa (play in education). Tämä näkyy mahdollisuuksina rakentaa majoja, kiipeillä puissa ja tehdä erilaisia projekteja niin ulko- kuin sisätiloissa. Leikkipedagogiikan avulla lapset oppivat valtavan määrän sosiaalisia taitoja ja tilannekohtaista joustavuutta (resilience). Tällaiset yleiset inhimilliset taidot ovat koulussa suoriutumisen ja elämässä pärjäämisen keskeisiä elementtejä, kertoi meille koulun vararehtori. Näin koulu voi olla omalta osaltaan tukemassa kotoutumista ja luomassa toivoa lasten ja heidän läheistensä elämään.

Kuten Noble Parkin esimerkki osoittaa, toivon luomiseen tarvitaan vahva arvopohja. Myös suomalaisen kotouttamispolitiikan tulisi perustua tietoisesti valituille vahvoille toivoa luoville käytänteille, joilla on globaali merkitys. Tämä tarkoittaisi esimerkiksi sitä, että maahan tulleelle nuorelle opetettaisiin taitoja, jotka ovat merkityksellisiä riippumatta siitä, missä maassa hän tulevaisuudessa asuu. Tällaisia globaaleja taitoja voisivat olla esimerkiksi toisten kunnioitus, erilaiset vuorovaikutustaidot ja omien vahvuuksien tunnistaminen sekä niiden käyttäminen, kuten Noble Parkissa opetetaan.
Tämän suuntaiseen kotoutumispolitiikkaan ollaan jo siirrytty muun muassa Ruotsissa, jossa on pohdittu erilaisten taitojen opettamisen merkitystä maahan tulleille nuorille riippumatta siitä, että heidän lähtötasonsa on usein heikompi kuin ruotsalaisessa yhteiskunnassa kasvaneilla lapsilla ja nuorilla. Haastattelemamme asiantuntija korostaa toivon luomisen tärkeyttä. Nuorille tulee näyttää, että heillä on mahdollisuuksia mennä eteenpäin elämässään, etteivät he jäisi menneisyytensä vangeiksi.

\footnotetext{
"Tärkeintä on, että koulu toimii ja asiat normalisoituvat. Että he saavat tavallisen koulutuksen ja uskoa siihen, että pystyvät menemään eteenpäin. Että he näkevät mahdollisunksia. Meidän täytyy näyttää, että on olemassa mahdollisuuksia. Että välillä mennään ylöspäin ja välillä tullaan alas. Aina otetaan kuitenkin seuraava askel. On tärkeä huolehtia siitä, että notkahduksista ei tule liian syviä, vaan yritetään nähdä niitä mahdollisuuksia. Me olemme myös tehneet töitä...He sanovat, ettei ole mitään väliä, jos emme saa jääd. Mutta me sanomme, että on parempi, että käytte koulua, olittepa sitten [tulevaisuudessa] missä maassa tahansa. Teillä on sitten enemmän erilaisia taitoja. Ei ole mitään väliä sillä minne maahan päädytte, mutta älkää jääkö passiivisina makaamaan." (Haastattelu MR, 2017.)
}

Ruotsissa kaikkien nuorten tasa-arvoinen kohtelu nostetaan tärkeänä tekijänä esille. Haastatteluja tehdessämme kuulimme useamman kerran kuinka: "Här $i$ Sverige är vi alla i samma lådan". Tulkitsimme lauseen siten, että toimijat halusivat uskoa siihen, että ruotsalaisessa yhteiskunnassa pyritään siihen, että kaikki ovat tasa-arvoisessa asemassa. Nuorten parissa työskentelevä haasta- 
teltavamme kertoi, että heidän työnsä tavoitteena on, että jokainen yksin maahan tullut voisi kokea saman kuin "tavallinen ruotsalainen nuori”. Tämä näkyi esimerkiksi kesäleireinä ja ystäväperheinä, joissa nuoret saivat tuntumaa siihen, miten ruotsalaiset nuoret elävät arkeaan. Myös lääninhallinnossa maahanmuuttoasioiden parissa työskentelevä haastateltava painotti yhdessä tekemistä: "verkostossa meillä on mahdollisuus keskustella monenlaisista kysymyksistä ja yritämme päästä yhteiseen näkemykseen siitä, mitä voimme tehdä yhdessä, millaisia ongelmia on ja mihin voimme rahamme käyttää".

Ruotsissa onkin kehitetty yksin tulleiden hoivaan liittyviä käytäntöjä ja pyritty paikallisesti vastaamaan muuttuviin olosuhteisiin. Muun muassa pitkien oleskelulupaprosessien myötä nuorten henkinen pahoinvointi alkoi näkyä useassa asumisyksikössä, kertoi KeskiRuotsissa sijaitsevan lääninhallinnon virkamies meille haastattelussaan. Pahimmillaan osa nuorista oli itsetuhoisia. Nuoria alkoi myös kadota asumisyksiköistä. Erityisesti nuorten katoaminen huoletti haastateltavaamme, sillä 2016 tehdyn kartoituksen mukaan Ruotsissa oli tuolloin yli 1800 kadoksissa olevaa yksin tullutta lasta tai nuorta (Akbar 2016). Haastateltavankin alueelta lapsia oli vuosien 2013-2016 välisenä aikana kadonnut yli 100. Haastateltavamme painotti, että erityisesti viranomaisten ja nuorten kanssa työskentelevien tahojen tietoisuutta on lisättävä ja pohdittava, millaisia tukitoimia tulisi luoda katoamisten varalle ja kuinka estää lapsia ja nuoria katoamasta. Hän korosti useaan otteeseen yhteiskunnan vastuuta ja oikean tiedon välittämisen merkitystä. Tällaiset pieniltä tuntuvat teot ovat osa yhteiskunnallisen toivon luomista ja asioihin tarttumista ennen niiden paisumista liian suuriksi ratkaistaviksi.

Suomalaisen kotouttamispolitiikan tulisi pystyä luomaan ja ylläpitämään toivoa yksin maahan tulleiden nuorten elämässä.Valitettavasti Suomessa ei vielä avoimesti tunnusteta, että maahanmuuttopolitiikan jatkuvat kiristykset vievät pohjan kotouttamistoimenpiteiltä. Ennen kaikkea nuorten kotoutumisesta näyttäisi tulevan "temppurata", jonka läpäiseminen ei kuitenkaan takaa turvallista tulevaisuutta Suomessa. Tässä tilanteessa on erityisen tärkeää kysyä, kuinka huolehdimme näistä nuorista. Kohdataanko nuoret jatkuvasti hallinnan kohteina vai välittyykö kohtaamisista hyväksyvä ja empaattinen yhteinen tulevaisuus?

\section{LOPUKSI}

Suomalainen yhteiskunta ei aktiivisesti luo toivoa kaikille jäsenilleen eikä myöskään ylläpidä myötätuntoa. Viime vuosien kiristykset turvapaikka- ja pakolaispolitiikassa ovat yksi esimerkki hallintokäytännöistä, jotka synnyttävät pelkoa ja toivottomuutta. Yksin tulleet alaikäiset turvapaikanhakijat ovat saaneet ennätysmäärän kielteisiä päätöksiä ja perheenyhdistäminen on tehty lähes mahdottomaksi. Pitkittyneiden päätöksentekoprosessien aikana nuoret ovat kuitenkin hiljalleen alkaneet kotoutua Suomeen: elämään on syntynyt uutta toivoa. Nuoret tahtoisivat rakentaa tulevaisuutensa Suomeen, mutta määräaikaisten ja lyhyiden oleskelulupien ketjutus tai pahimmillaan kielteinen päätös vuosien oleskelun jälkeen vievät pohjan pois elämältä. 
Tutkijat ovat useasti todenneet, että yhteiskuntien jousto- ja selviämiskyky on kiinni käytännöistä, joilla ylläpidetään yhteiskunnallista luottamusta. Toivo ei ole kansalaisuuteen sidottu yksilön ominaisuus, vaan sillä on laajempi yhteiskunnallinen merkitys: toivo mahdollistaa yksilöiden ja yhteisöjen selviämisen arjessa ja toimimisen paremman yhteisen tulevaisuuden puolesta. Erityisesti haavoittuvassa asemassa olevien lasten ja nuorten oman äänen huomioiminen ovat osa toivon ja luottamuksen rakentamista.

Tutkimuksissamme olemme toistuvasti havainneet, ettei yksin tulleiden kokemustietoa ole hyödynnetty palvelutarpeiden kartoittamisessa. Tämä on johtanut muun muassa toimimattomiin asumisen käytäntöihin, yksinäisyyteen ja kotoutumisen ongelmiin. Tulevaisuuden palveluketjuissa tulisikin korostua joustavuus ja nuoren rooli aktiivisena palveluiden käyttäjänä eikä passiivisena hallinnan kohteena elävänä yksilönä.

\section{KIITOKSET}

Tutkimusta rahoittaa Suomen Akatemia (SA266161 ja SA304146)

\section{KirjallisuUs}

Akbar, Avin Ali \& Gustaffson, Anna-Karin \& Kullaner, Mats \& Tönnes Lönnroos, Lisa \& Verständig, Natalie (2016) På flykt och försvunnen. En nationell kartläggning av ensamkommande var som avviken. Raport 2016:25. Stockholm: Länstyrelsen Stockholm.

Australian Bureau of Statistics (2016) No- ble Park. http://www.censusdata.abs. gov.au/census_services/getproduct/census/2016/quickstat/SSC21940 Luettu 26.2.2018.

Australian Bureau of Statistics (2014) Where do migrants live? Australian Social Trends. http://www.abs.gov.au/ausstats/abs@.nsf/Lookup/4102.0main+fea tures102014 Luettu 26.2.2018.

Hage, Ghassan (2003) Against Paranoid Nationalism: searching for hope in a shrinking society. Annandale: Pluto Press. Hage, Ghassan \& Papadopoulos, Dimitris (2004) Ghassan Hage in conversation with Dimitris Papadopoulos: Migration, hope and the making of subjectivity in transnational capitalism. Journal of Critical Psychology 12, 107-121.

Kleist, Nauja (2017) Introduction: Studying hope and Uncertainty in African Migration. Teoksessa Kleist, Nauja \& Thorsen, Dorte (toim.) Hope and Uncertainty in Contemporary African Migration. New York and Abingdon: Routledge, 1-20.

Kuusisto-Arponen, Anna-Kaisa (2016a) Yksin tulleiden nuorten kohtaaminen ja sosiaalinen tuki arjessa. Teoksessa Veronika Honkasalo, Karim Maiche, Henri Onodera, Marja Peltola \& Leena Suurpää (toim.) Nuorten turvapaikanhakijoiden elämää vastaanottovaiheessa. Nuorisotutkimusverkosto, Liike-julkaisusarja, 33, 34-38.

Kuusisto-Arponen, Anna-Kaisa (2016b) Myötätunnon politiikka ja tutkimusetiikka Suomeen yksin tulleiden maahanmuuttajanuorten arjen tutkimisessa. Sosiologia 53 (4), 396-415.

Kuusisto-Arponen, Anna-Kaisa \& Korjonen-Kuusipuro, Kristiina \& Tuominen, Jaakko (2017) Yksin tulleiden maahanmuuttajanuorten asumisen ratkaisut. Politiikkasuositus. http://www. transculturaltrust.net/wp-content/uploads/2017/05/Yksin-tulleiden-maahanmuuttajanuorten-asumisen-ratkaisut-2017.pdf

Laki kotoutumisen edistämisestä 30.12.2010/1386.

Mattingly, Cheryl \& Jensen, Uffe Juul (2015) What can we hope for? An exploration in cosmopolitan philosophical anthropology. Teoksessa Sune Liisberg, Esther Oluffa Pedersen \& Anne Line 
Dalsgård (toim.) Anthropology and Philosophy: Dialogues on Trust and Hope. New York and Oxford: Berghahn Books, 24-55.

Migri (2016) Humanitaarista suojelua ei myönnetä enää, uudet maalinjaukset Afganistanista, Irakista ja Somaliasta. Tiedote 17.5.2016. Osoitteessa https://migri. fi/artikkeli/-/asset_publisher/humanitaarista-suojelua-ei-myonneta-enaa-uudet-maalinjaukset-afganistanista-irakistaja-somaliasta.

Pedersen, Esther Oluffa \& Liisberg, Sune (2015) Introduction. Trust and hope. Teoksessa Sune Liisberg, Esther Oluffa Pedersen \& Anne Line Dalsgård (toim.)
Anthropology and Philosophy: Dialogues on Trust and Hope. New York and Oxford: Berghahn Books, 1-19.

Reed-Danahay, Deborah \& Brettell, Caroline (2008) Citizenship, Political Engagement and Belonging: Immigrants in Europe and the United States. New Brunswick, New Jersey, and London: Rutgers University Press.

Tilastot yksin Eurooppaan tulleiden lukumääristä 2015 ja 2016 EUROSTAT, Migri (Suomi), Migrationsverket (Ruotsi), Bundesamt für Migration und Flüchtlinge (Saksa). 